\title{
SOME OBSERVATIONS ON THE NEURONAL MECHANISM OF OPTOKINETIC NYSTAGMUS
}

\author{
By \\ A. WATANABE
From the Department of Oto-Rhino-Laryngology, Niigata University School of Medicine
(Chief: Prof. M. Morimoto, M.D.)
The Brain Research Institute, Niigata University School of Medicine
(Director: Assist. Prof. N. Maruyama, M.D.)

Unitary activities were recorded from occulo-motor nucleus and optic nerve in rabbits by means of super-fine microelectrodes with the aim at clarification of neuronal mechanism concerning the reflex arc of optokinetic nystagmus.

1) The unitary activities of occulo-motor nucleus when optic nystagmus was produced were as follows:

The discharge rate increased or decreased with turning an optical cylinder till it reached to a certain rate, which continued to the beginning of nystagmus. This phenomenon made us consider that bulbs were kept in a deviated position.

The impulses to the occular muscle which rested in quick phase decreased promptly to a minimum discharge rate just before the beginning of a quick phase and increased gradually with the beginning nof slow phase. The change of discharge rate of the impulses to the occular muscle which contracted in quick phase corresponded to the course of nystagmus.

2) The occular movement recorded with electronystagmography was accelerated towards the foveopetal direction of the image of a stripe when discharges of an optic nerve fiber which derived from the area close to the fovea were increased.

Discharges of an optic nerve fiber with derived from the area close to the fovea showed constantly marked increase when the image crossed over the receptive field by foveo-fugal shifting; on the contrary this marked increase was not shown by foveo-petal shifting of the image.

When the image left the fovea in slow phase, occular movement was so accelerated that the image could be caught on the fovea by increase of discharge from the nerve fibers derived from the area close to the fovea. Even when the image drew nearer to the fovea in quick phase, occular movement was not accelerated and it decelerated intensively after the image crossed over and left the fovea.

3) In order to clarify the cause that the dischasges of the unit derived from the area surrounding the fovea reacted a different way by shifting direction of the image, the unitary responses of optic. nerve to shifting of stripes were examined in immobilized animals. An analysis of unitary discharges derived from periphery of the optic field revealed the existence of suppressive field on the eccentric side of and close to the receptive field. This unit showed the marked response by foveo-petal shifting of the image on the contrary to the unit derived from the area close to the fovea. These fact were considered advantageous for the formation of quick phase.

In the area around the fovea, suppressive field was considered to be on the concentric side of the : receptive field, which, however, was to be proved. 


\title{
【鳥居恵二名誉教授古稀記念論立】 視性哏振反射路の神経機序に関する研究序説
}

\begin{abstract}
新渴大学医学部耳鼻咽喹科教室（主任：森本正紀 教授）

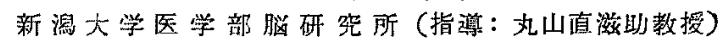

渡 辺 昭 太

\section{緒言}

視性眼振 optokinetic nystagmus は Bárány (1907) ${ }^{\text {9) }}$ が Eisenbahn-nystagmus と記載したのが全くの最初 であるといわれている。

視性眼振の意義について福田 ${ }^{86)}$ は, , 視性腿振の発 来は，移動する事物を的確に個々の動さとして誌識さ せ，移動する事物に対し適応させる反射である.”とい

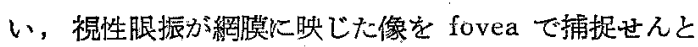
する反射運動である，との考え方は現在多くの人から支 持されている。

迷路性腿振との関連について森本 3゙は，“迴真によ る人の眼振所見を検傠すると, 視覚の有㳑によつて量的

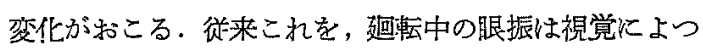
て助長され，後腿振は抑制ざれるといつて招る。これで

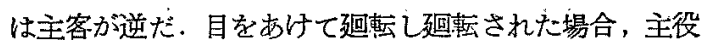
を演ずるのは視性眼振であり，前庭眼振は視性眼振がお こり易いよらにこれを支持し，耐者協力して fovea で 物をつかんで central vision を可能ならしるる可く働 いて祘る。”と述べている，即号腿振反射に対しては迷 路刺㦸よりも視刺㦸が基本的のものであり迷路はこれに 対し協同的に働くものと考えている如くである、福田等 む同様の見解をとつている。

視性腿振は, 視対象の移動方向一向ら綏徐相とその反 対方向への急速相,この 2 相より構成されるが, Kestenbaum (1930):あ)によれば，緩徐相は対象物を固視す るためのものであり，急速相は眼筋を弛緩せしめんとす る傾向とある方向に視軸を転㵲せんとする自発的な意志 によるあのである.としている。

Bárány (1921) 4) は視性腿振解発には，1) 対象物 に腿琲を固定凝視せんとする impulse，2）動く対象物 を追跡する impulse，3）続いて視野内に新に登場する 対象物を把握すべく眼诪艺引门き戻す impulse，以上 3 程 の impulse を必要とすると述べた。

急速相の由来に関して, Brunner (1936)きは中心 位に眼冰を厣さんとの腿反射であると述べ，Bender
(1954)6) 6眼球方中心位から離孔る機棈（緩徐相を形 成する機褠) があると同様に，眼垡を中心位に引可きさ んとする機構 (急速相を形成する機構) があるとし, 後 者を eye-centering と呼称した。即ち急速相は腿域を 中心位に店寸機構であつて，䉼に視野内に現われる対象 物に視䩜を向けることが急速相になるという見解を否定 している.

しかて上記の視性腿振㙨原に関する諸説は,いずれる 末だ 奏証的な值接の証朋を久き，憶测の域をでていな W.

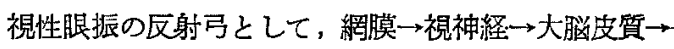
皮質視覚中枢 $\rightarrow$ 皮質下伝㙞路 $\rightarrow$ 動腿神経陔 $\rightarrow$ 眼筋，この 経路を想定するものもあるが，脳破壊実験の結乘よりし て，大脳は眼振反応調節的規制を与をているが基本的 反射路は大脳を経由しない，との考方方が有力となり つ〉ある. 又視器系と迷路系之の密接な関連を強調する むのも多い.

眼振発来の機度とその反射路については，従来各種の 実験と考察がなされてきたが，その多くは脳中枢の各領:

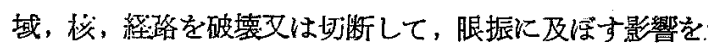
観察して解析を試みている。しかし脳の各部や経路を意 のまつに正確に破滾することは非常に困埃であり, 又破 㙹による脳の血行障碍はもとより種々の副損傷を起し, 更に切断に際しては損傷部と neuron 連鎖を有する部 位に一追性の shock とも称すべき diaschisis 現象が起 る事も明らかにされている，又たと破壊実験によつて ある程度の反射伝道経路を知り得たとしても，作動㙨序 は破壊実験では絶対に証明できない，従つて視性眼振発: 現時に反射路各部の動作を直接記録する事が这要となる か゚，この種の矿究としては筋電図を利用した碗究が散見 されるのみで, 視性腿振反射弓の神経㙨序の解明に直接 メスを加えてこれを実証したるのはないといらてす避 ではあるまい，特に知覚路側の観察は全く茾困て，網膜 上を移動する対象物が，いかなる情報によつて映像の移 動が伝えられるかさえ，生理学上今迄明かにされていな 
い有様である.

網膜及び視神柽生理に関しては Hartline, Kuffler, Lennox, 本川，富田等の業瞔があるが，いずれる光又 は色光に対する反応の研究であつて, 動く目標に関して 研究の手を染めたものはない

私は網膜上を動く線条がどのような情報として中枢に 妘えられ，それがいかにして neuron を介して終局の nystagmus なる motor pattern に変るか, その間の 機構を追求せんとし, 近年発達してきた微小電極法を用 いて解明を試みた。

\section{実 験 方 法}

実験動物としては体重 $2 \mathrm{~kg}$ 前後の家鬼を用いた. 視 牲眼振を解発さすには動物が覚醒しておることを必要と するので, 比較的単時間に覚醒するように手術時の麻酰 はネンプアール 0.3〜0.5cc/ kg の静注を行つた.

現象の記録時には無麻酔の状態を必要とするため，動 物の動きを最少限に防止せねばならない、そのため前手 術として, 先ず両側上腕神経鋠を切断し, 脊骾を第 3 腰 椎の高さで離断した．背筋の運動を共に制限するために はできるだけ高い位で脊随離断を行うことが望ましい が, この高さょり上では血圧但下, ひいては全身状態の 悪化をきたすことが多い，又脳実質の博動性又は呼吸性 の動摇を除くために，小脳延䯣橧又は第 1 形椎々第 2 頸 椎の間を開放して䯣液の流出を計り，液王を乔して起る 動摇を排除するよう努めた。

視性眼振の発現を必要としない観察の場合は, 上腕神 経叢切断, 脊髄離断等はこれを行わず, クフーレ剂(ア メシゾール）の筋注及び静注を行つて体動を止め，人工 呼吸器により人工呼吸を行つた。いずれの場合でも気管 カニニーレを挿入し，又随時静注ができるように腋窝静 脈で静脈うテーテルを挿入しておいた．室内温度は 26 ${ }^{\circ} \mathrm{C}$ 前後に保つて動物の保温に留意し，それにもかわわ らす゚体温の低下を見た時には湯ハンポを使用した。

本実験に用いた電㥛は極好繊細であり, 又眼振解発 には殆しど無麻酔の状態を必要とするので, 動物の固定 には非常に難渋した．家洍は骨質が弱く充分に強力な固 定ができないため，劸い多点固定となるが，固定点が多 くなると動物の視野を塞ぐ結果となり，ひいては視性眼 振の解発を妨げる事となる. 従つて本実験には種々の特 殊固定バーを考案した. 固定器の原型は Clarke-Horsley 型で，口蓋，支右眼窝下縁，頭蓋左右側頭骨及び左 右後頭骨の計 7 点で固定したが，各バーは固定点より直 ちに視野外方向に折れ曲り，動物の視野内に入ら妨内う
に配置した.

視性眼振解発流汭ン゙ムが従来慣用されているが，本 実験には㮴々の障碍を尘ずる、実験装置の微細な動きも

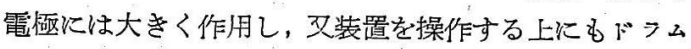
の廻転は妨け゚になる面が多い，そこで Jung 年) の方法 に準じ、ドンを廻転する代りに線条光を廻転し円筒状 のスクシーン上に投射する方式をとつた（第1図).円 筒スクシーンの後方は動物の視野に入らぬ部分だけ切除 し, 操作の便を計つた. 線条数恃全周 $360^{\circ}$ K 16 本であ り, 線条迴転は数分ないしは十数分 $\mathrm{I}$ 迴桯程度の速度か ら除々に加速的儿迴枟度を上昇させた。

第 1 図 A) 項及び C) 項の実験に用いた 実験装置

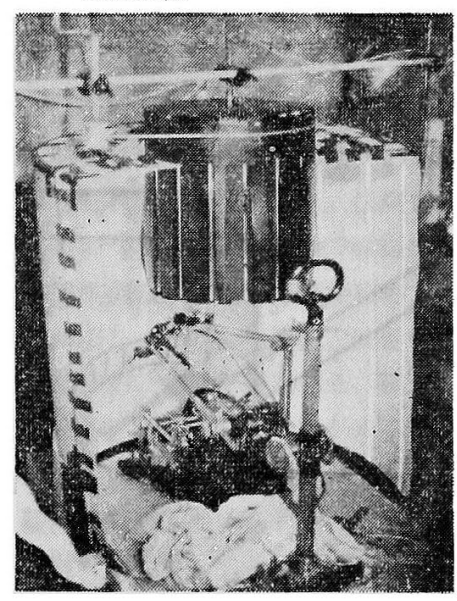

第 2 図Ｂ）項の実験に用いた実験装置

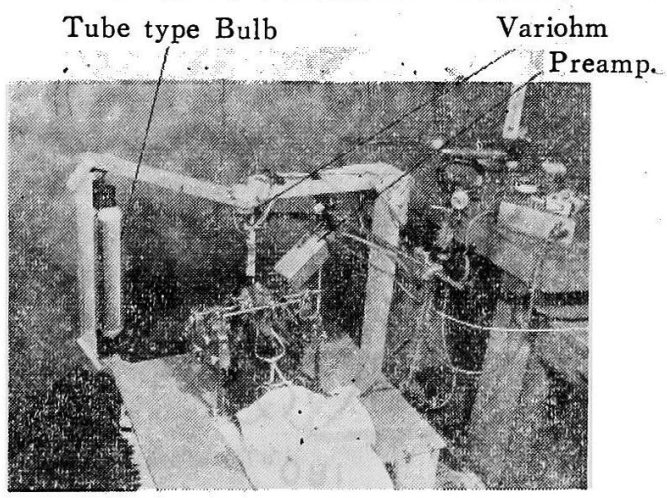

移動目標に対する喈報型式を钼察するためには，眼珢 を固定して只 1 本の線条を移動する方式をとり，光源と して長管球電琲を使用した（第２図）．管球を垂直に立 て，その表面の腿冰方向に问う面上を細く約 $1 \mathrm{~mm}$ の䦓 
償を残してこれを線条光とし，その他の管表面は光線の 洩ら双上うすべて完全被覆した．線条光が明る 過ざる

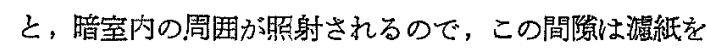
8 枚重ねて貼り，I本の線条以外㒂恮く見えないよう

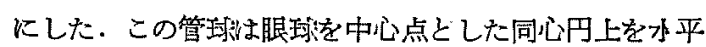
に迴転する如く考案し，迴転面上には眼球の前方を 00 とし尾方を $180^{\circ}$ とした目盛を附した。線条光の备位置 はバリオームを管球と同軸に迴鞋するようにし， $1.5 \mathrm{~V}$ の乾電池を利用して、バリネームによる分割電位差を゙ ッシロスコープの1軸炕導き管面上の高さで判定できる ようにした（第3図）.

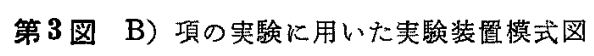

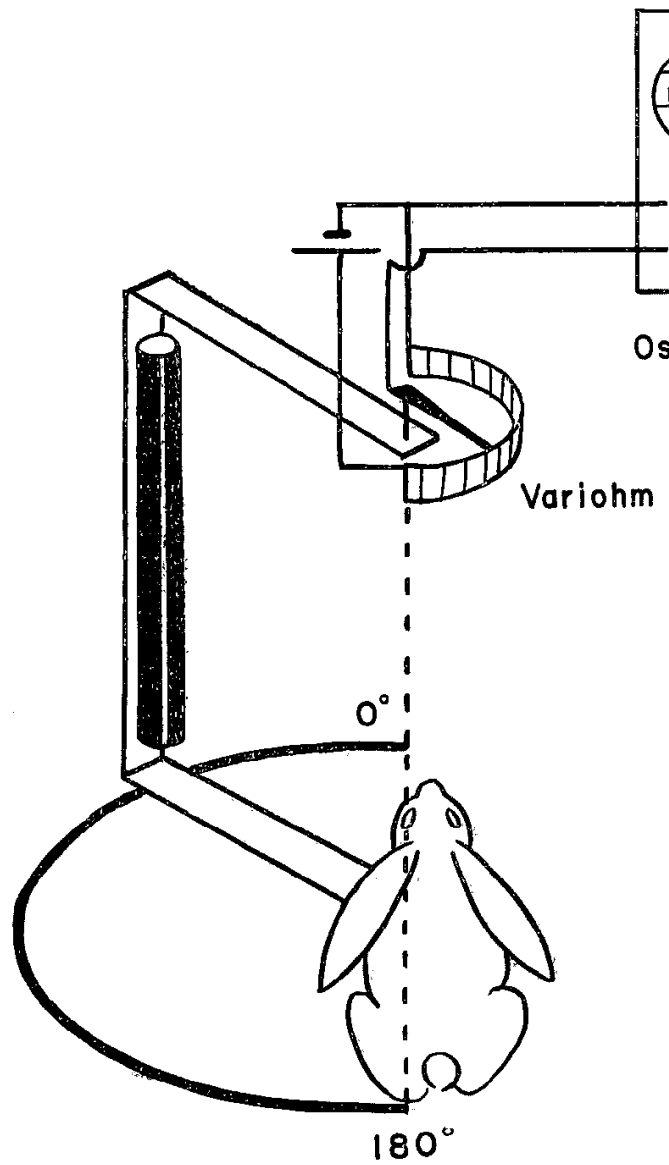

動跟神経核誘導には，先す頭蓋頭頂部骨を広く除去 し, 次いで硬䋞膜を切開して大脳を露呈, 両側大脳半球 を左右に排して，上丘を露出する：これを貫いて，予め 脳標本により計測した方向と距離に従つて, 動眼神経核
に電極を刺入した。

視神経の露出には，前頭骨から頭頂部骨を広く除去

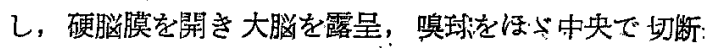

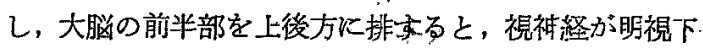
におかれるので，直視下で電極を刺入した．視神経上り， の誘尊は常に視神経交叉前の太側神経束上り行つた。

誘導電極は $3 \mathrm{~mol} \mathrm{Kcl}$ を潎したがン.ス,毛細管電極を、 使用した：細胞外㛬導が目的を゙あつたので，電極抵抗仗

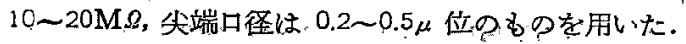

電極操作装置として Peterfi 型、さクロ・ヨこプレー

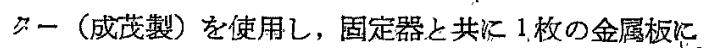
固定して，動物之電極間は常に相対的に不動とした，視 神経刺入に際しては，刺入角度の関伱加ら，ミ ニアチア・マイクロ・マニプレーター(成茂製)、 を用いた。

眼球運動の記録には同心型針電極汇より， E.N.G. を誘導した. 電極は $1 / 2$ 剑に純銀エナ. メル被覆線を封入したもので，電㥛自身の分極 電圧は常に $1 \mathrm{mV}$ 以下になるよう留意し, 使用: 状態での電極抵抗は各々 $10 \mathrm{~K} \Omega$ 以下とした。

超微小電極よりの電位 (unitary spike) は, cathode follower 前置增幅器を通し, 同心電 極よりの電位 (E.N.G.) は眼琲自身の分極を保 償するために，直流保償回路を通して，それぞ れ別の自颠禣賞型直流增幅器で增幅し，3光軸 オッシロスコープで 観察記録した。1軸にE． N.G.を. 䩜に unitary spikeを，残りのl㖕 には時間目㹂を入れた。

\section{実 験 結 果}

A) 動眼神経核の放電様式

第 4 図は線条迴転時同一 unit より誘導され た spikeである.（1）は線条を左眼向きに迴 転させた場合であり，(2) は右腿向き迴転の 場合である。上が E.N.G. であり耐図に尔い て左右逆方向に眼振が発現している. spike， discharge は迴転方向のいかんにより眼振発現: 前にすでに spike rate が倛り, 眼筋の tonus. が異つている事を示す。この tonus の変化は 線条の迴転之同時に始まり，図中に見られる眼 振緩徐相の経過とほざ一致して变似する，肉眼観察です 同時に楾条建転方向に眼球偏倚が起り，眼振の起つてい， ない相では，偏倚した位置で腿球が固定されているのが、 見られる。 


\section{第 4 図}

（1）眼振発現時の腿筋運動核の unitary discharge (左腿向き䞟枟)

(2) 限振発現時の眼筋透動核の unitary discharge (右腿向き奋轻)

(1)

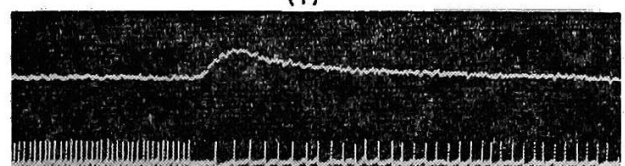

mommmmminominmm

(2)

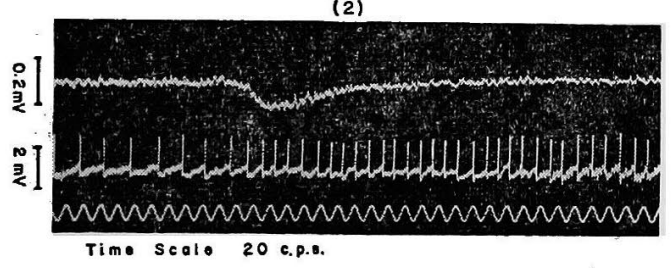

眼筋運動神経の untary discharge は眼振発現前に, (1) では spile の間隔はせばまつて密に， (2)では spike 間は離開し, 廻転力向によつて逆の態度を示し， 各々眼球の偏倚が起つている事を示している.こっで注 目しなければならないのは，眼振時の spike rate で ある. 左右迴転いずれの場合でも, 眼振発現に一致して spike rate に著明な変作が現われるが，（1）では，腿 振急速相が起ると同時か, むしろ僅かに先んじて急激に tonus の減弱が見られるに対し, 区対方向廻転転即ら右 眼向きに線条を迴転した（2）の昜合は，眼振各相の経過: に全く一致して spike rate が変化している. しかも庄

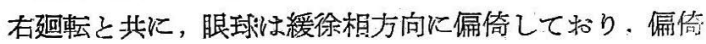
した位置から直らに急速相が発現する事を思わせる．急 速相発現前に偏倚が更に緩徐相方向に增加する所見は全 く見られなかつた。

Bárány によれば視性眼振解発には，先ず第一に視野 内の対象物を凝視する事が主要な要素をなすとし, Jung

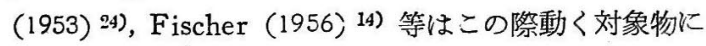
向けられる注意力の集中が眼振解発に重要な役割を持い と述べている. しかし腿振数の非常に少い状態, 所謂つ きの悪い状態ではいかなる眼位をとるか, 説明していな い. 本実験の結果から見ると, 腿球け緩徐相に偏倚した ま〉次の対象物を待つているかの如くである. 乙か子急 速相が現われる時にはとのま〉の眼位から直らに念速相 に入る.Bender 等によれば急速相は腿球を中心位に厌
そらとする eye-centering によるものとし, 页次の対 象物に服を戻すことは，視性眼振の急速相の機構に対し て殆んど大した役割を演じていないと考えているが， eye-centering の機序としては，当然腿筋の tenssion receptor からの情報が必要と考えられるので，この説

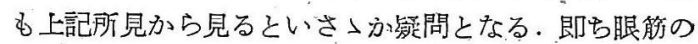
繁張のみが 原因で急速相が 発現するものとすれば，急 逨相発現の直前に必ず最高の眼球偏倚が見られる筈で， 急速相発現に先んじて緩徐相方向に腿冰が更に偏倚して から，急速相が発現しなければならぬわけであるが，本 実験の条件では急速相は緩徐相側偏倚の位置から全く直 ちに起つている. Bender のいう eye-centering が関係 しているとしても, 本実験条件では別の因子をも考える 必要がある.

Bender は又視性眼振は持続した刺战の最中にあつて る時に短時間の自発的中断がある事があるが，これは恰 む失神文は仮睡状態の如くであり，注意力の欠除による のであろらといつている. 本実験では眼振が発現しない 状態でも, 線条廻転中は眼球は緩徐相の方向に偏倚した ま〉の形で待機しており，無反応とは言い難い，即脃 速相準倩状態にあるものと思われる. 腿琲の待機位置に ついては実験条件, 実験動物のいかんによつて, 当然異 る場合もあると思われるが，このような状態が認められ る以上, 眼振が発現しない事をるつて直らに無反応と断 ずるのは早計であろう.

本実験の所見からすると，視性眼振急速相の発現は， eye-centering の作用が関係するとしても，別箇の直接 的因子により，眼球偏倚位において収縮していた筋が先 ず弛緩し，乙かるのちに拮抗筋が収縮して，急速相が形 成されるものと解される. eye-centeringは筋のtension receptor からの情報による ものであると思われるが， 急速相発現の直接因子は, 恐らく新に視野内に登場する 対象物によつてもたらされる impulse であろう . 続く 緩徐相は，対象物の移動につれて眼球がこれを追跡する ために起る腿球偏倚でありこの絽り返しが視性眼振を 構成与るので方ろう。急速相緩徐相発現の原因は, 前者 は新な対象物に対する注視把握が主因であり，後者は移 動する対象物の追跡と想像されるが，移動する線条が視 神経にどのような興窞を著き起し, 視器から送られた情 報がどのような機序によつて，上記の如き合目的的運動 を起すに必要な impulse に迄変形されるか，この問題 を検討するには, 視神経における反応様式の観察が必要 
となる. 次項にとの所見を記そう.

B）移動目標に対する視神経の放電㥆式

Hartline (1938) 19) は蛙の網膜飞光を照射し， 単一 神経線維よりこれに反応する spike discharge を誘導

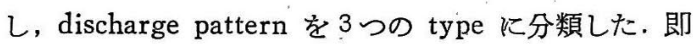
ち第 5 図に示す如く，光の照射洔のみ response を示寸 on type, 光を遮断して初めて response を示す off type, 両者のいずれにも反応する on-off type の 3 型である.

視性眼振は，黒地に白い線条を引いたドンムでも，白 地黑い線条を引いたドンムです発現されるのである が, いずれのドフムでも on-off type の unit に対して は殆えど同じ response patternを与をる筈である。こ れに反し on type 页は off type の unitはドラムの 線条の白黒いかんによつて異つた response を示す事に なる. 従つて眼振反射には主として on-off type の unit が関係するものではなかららか. on-off type の unit は数も非常に多く，網膜上に万遍なく分布している事が わかつているので，このような可能性は充分に考元られ る. 以下の実験では白線条を用いたが，黒線条を用いて る on-off type については全く同様の結果を得られるも のと思われる.

第 5 図光刺戟に対する視神経の unitary response (discharge rate diagram 模式図)
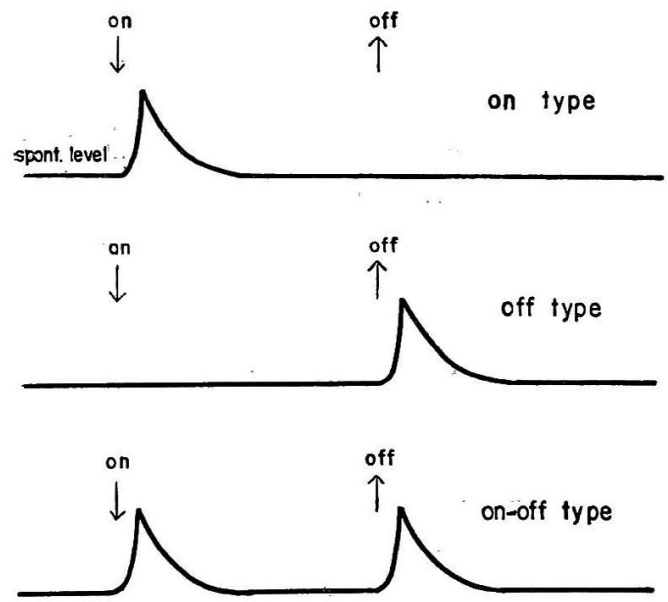

第6図（I）は，動物の眼球をクフーレにより不動化 して，1 本の線条を迴転した場合の視神経より誘導され た unitary response である. 実験には常に左眼を用 い，視神経交文前の左側神経束より誘導した。な扣この 実験では同一 unit から非常に沢山の記録を必要とする ために長時間を要するので，記録中 spike amplitude
第6図（１）䔟動線案に対与石祝神徍の unitary response (type I)

(1)

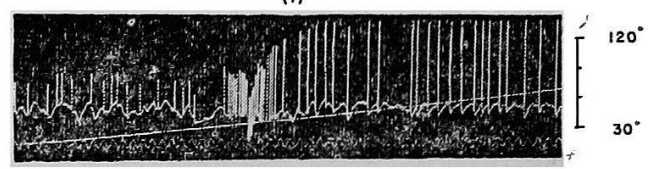

(2)

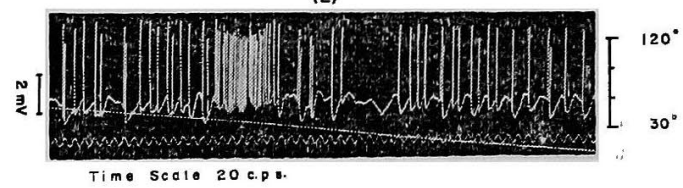

（II）散光の点隇に対する反応

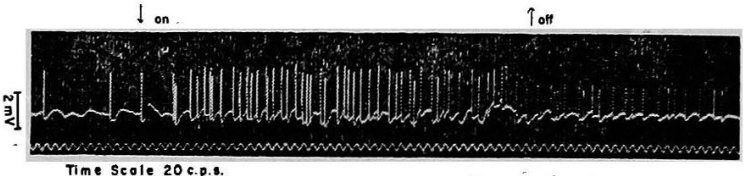

（II）線条光の点隇に対する反応
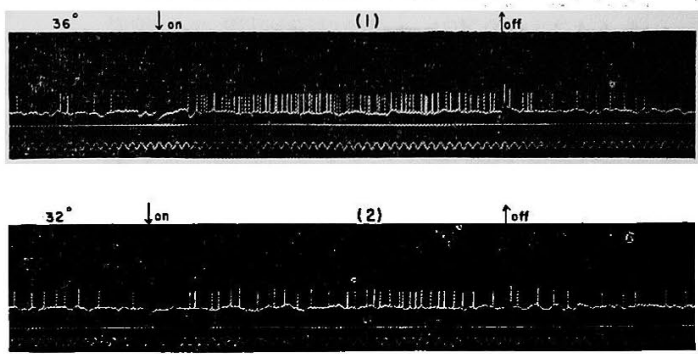

$26^{\circ} \quad \operatorname{lon}$

(3)

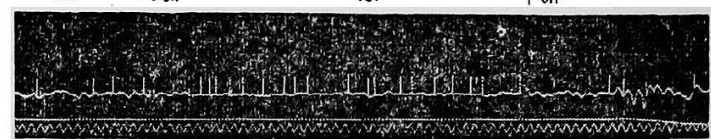

$20^{\circ}$ Lon

(4)

Toff
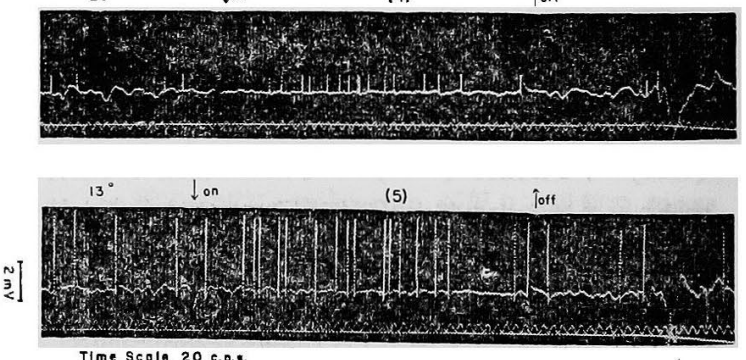

Time scale 20 c.p.s.

の変動を免れず，不本意ながらか」るデーァも採用せさ るを得なかつた. 但し spike amplitude の変化が gra- 
dual で同一 unit からの㮇澊である事を確信できるる

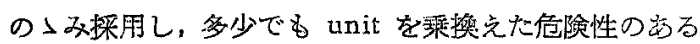
デースは破裹した．細胞外竡導のみを目標としているの で、電極はや今太いが，それでも尖端口径 $0.5 \mu$ 以下の

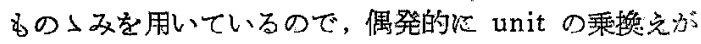
起る事は比較的稀であつた，例えば第6図はすべて同一 unit からの記録であるが，（I）の（1）及び（II）に見ら れる如く amplitude の変動は gradual で unit の乘㴽 えがなく, 同一 unit からの記録であることは確信でき る.

（1）、性泉条を移動した場合の記録で，(1)は線条を 前方 00方向より尾方 $180^{\circ}$ 方向へ移動した場合である. 線条の位置恍輌（第1軸）の高さで表わされており， この記録では字方より右方へ上䒜している線がこれに相 当し，線条方前方より後方へ移動する事を示している. この㭙網膜上の線条映像过屰に耳側より悬側へと移動す るわげである（第17 図参照）。眼球は線条が $73^{\circ}$ の位苜 にある時 papilla が照射される位置に固定されていた。

(I)の (1)の discharge pattern を荋ると, $30^{\circ} \sim 33^{\circ}$ で明膫な inhibition 次いで $33^{\circ}$ 〜370で強い response を示している（2）は線条を眼球の後方上り前方几盂転 した昜合で，第 1 軸は時間と共に下降している..網榺， 線条映像は鼻側より耳側入移動することになる，最初 $37^{\circ} \sim 32^{\circ}$ で強い response 次いで $32^{\circ} \sim 20^{\circ}$ で inhibition の起つているのが琶められる.この unit では線条 の移動方向により response と inhibition の配列が逆に なつているので,この unit は対象の移動を情報として 伝える能力を有すると言う事ができよう。

(け) は室内灯の点隇效果:を観察したもので, adapta tion'の斿々い on effect response を示している. off の後にも spontaneous discharge より遥かに多い discharge rate tation が和々く，点灯中の最後でも， spike rate が高 いためか子矨れないが, off によつて特に spike が增加 しているとも言い難いので, on-off type とはい山沶れ ない，光の点減はフンブへの電源 switch の点隇で行つ

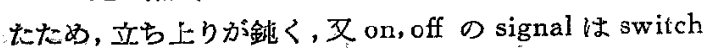
on, switch off と一致させて入れであるので, off の 位置は光でのるの〉 off と一致した以篦である。この点 off response の解釈には特に注意孛恶する。on, off い ずれの response も立ち上りが覀いので on 又は off の 直後の response fattern は定烈的な型をとつていない。

（III）は第 1 軸の示す位固に線条を固定して，その位
置で管球の点隇を行つたものである．即ち網膜に対して はある程度の限局照射になつている。この場合も室内灯

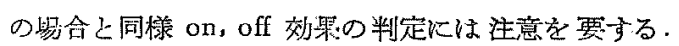
response 你 $36^{\circ}$ で最も強く現孔，照が on type resconse で多る. inhibition は $20^{\circ}$ と $26^{\circ}$ の off の位置 に最も昭瞭に現われている．13では反応子抑制も殆え ど見られない.

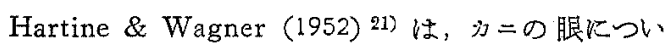
て1つの何腿に微小光照射を与え, 神経線維より定常的 な spike discharge が記録されている時に，隣接の他 の個眼を照射すると，先の個眼の discharge が萻明に 娍少する事を認め，これを lateral inhibition と名付 けた.

Kuffer (1952) 26) は, 猫の朣孔から刺战光を送り， 単一神絰節細胞の活動定記録し，その receptive field を測定した. 同一 unit の同じ receptive field 内でも， 中心部に光を当てた時 on response, 周辺部に光を当 てた尿 off response, その中間带の照射で on-off response を示す on-center unit と, 周边部照射で on response, 中心部照觓て off response の見られる off-center unit とがある事を知つた.そしてこの on field と off field は互に拮抗的に作用し合い，2 個の微小光 刺晖を両 field に同時に与兄ると, 弱刺㦸に対する response が抑制されることを見出した。このように on field と off field は互に拮抗的な排制作用を有する事が

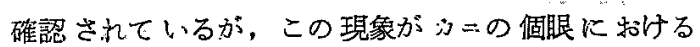
lateral inhibition と同じであるかどらが疑問である.

沢・丸川 41) 等は，猫の眼球を破壊することなく視神 経交实前より誘尊し，散光刺战に対する response を調 ベ,やばりon, off, on-off type を分類しているが,各 type の反応 pattern は蛙を用いた Hartlire 等の報告と多少 異つている．沢・丸山等はこの差を微小光刺㦸と散光槑 㦸上の差であるとし，動物の差や眼球の状態及び誘圎部 位の差に基因寸るのではないと考夏ている．即吕散光刺 㦸では誘導 unit の反応野にも抑制野にも同時に刺㦸が 加わるので，抑制野の影響は latency が長いためる，第 7 四 (2)の如き response 聖究示したものとしている.抑制 野の影響は latency が長いので、隣接 unit から網膜内で transe-天ynaptic に抑制を受けるものと推定し、トはり lateral inhibition と考克, Hartine の蛙の央歌のデ ーラにるこの傾向が現われている事を指摘している。

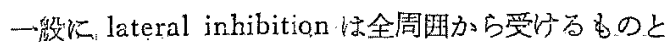
胃なされ，事実鼬条を固定して点隇した些験を付細に点 


\section{第 7 図}

(1) Hartline: on type

(2) Sawa \& Maruyama: on type response on-off type inhibition (discharge rate diagram) (1)

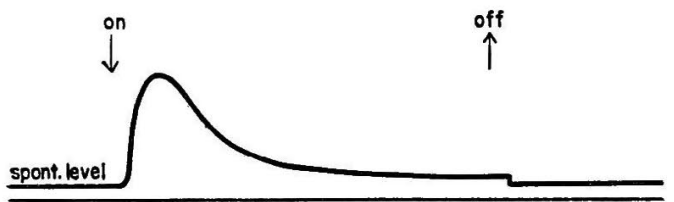

(2)

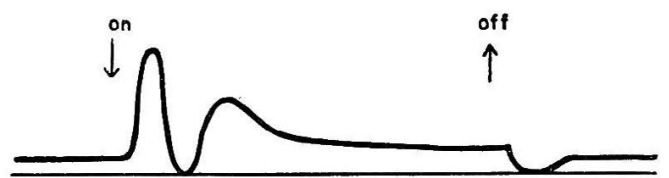

検すると，多少とも抑制を与をえている領野は，反応野の 両側にまたがつている場合が多い，しかし非常に強力な 抑制野が特に1側のみ存在しているような unit では, 対象の移動を情報化する事が可能であり，第6 図の response pattern は正にこれに相当する.

第 8 図移動線条に対する視神経の unitary response (type II)

(1)

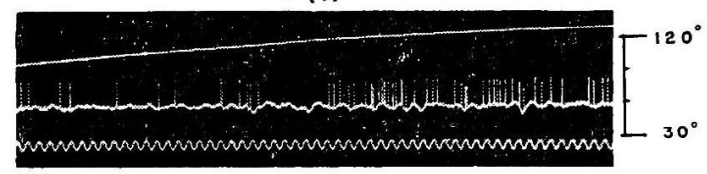

(2)

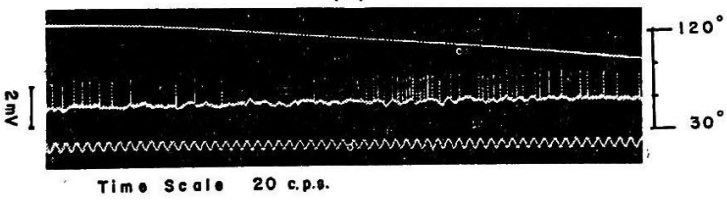

これに反し第8図に示した unit では，抑制と反応が 線条の移動方向とは無関係におこり, 先ず抑制次いで反 応という風に時間的前後で配列している.このような unit では対象の移動を情報化する事ができない、しか しこのような unit が全周からほら゙平等に抑制をらけて いるとは断言できない，何故ならば，本実験では限局照 射といつても線条光を用いているので, 抑制野と反応野 が上下に配列してい扎ば，全く同じ位直で抑制と反応が
起り，どちらへの移動でも，散光を単に点隇したたけの 場合之同じ反応が起る事になる. 全周から平等に抑制を 受けるものか，あるいは上下配列であるかについては線 条を樦にして上下方向に移動可れば判明する筈である が, 残念なか゚らこの実験は行つてないので, 一応両方の 可能性を保留する事に止るる。

第 9 図

(I) 移動線条に対する視神経の unitary response (type II)

(1)

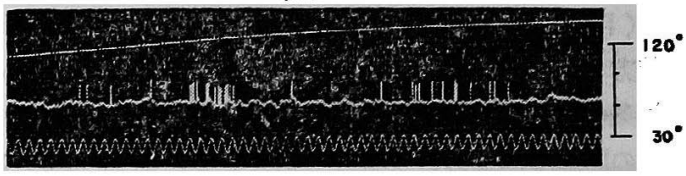

(2)

$\stackrel{n}{\gtrless}$ ¿ I

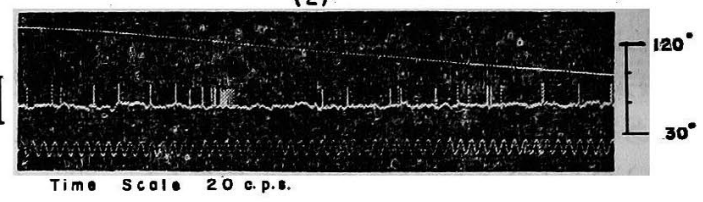

（II）移動線条に対する視神経の unitary response

(I)
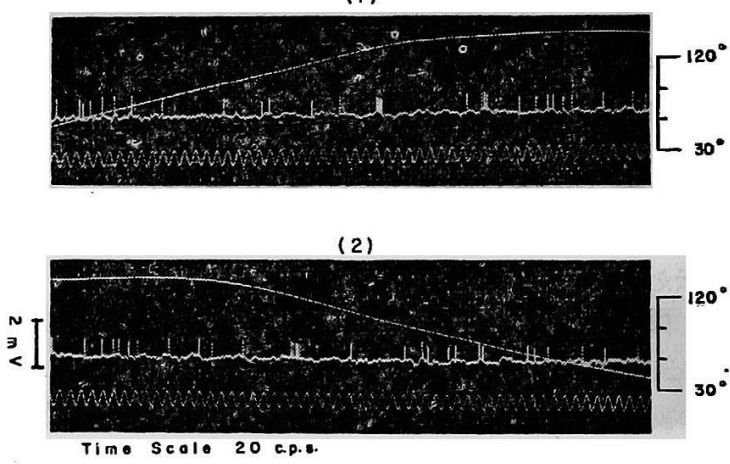

（四）移動線条に対する視神経の unitary response (I)

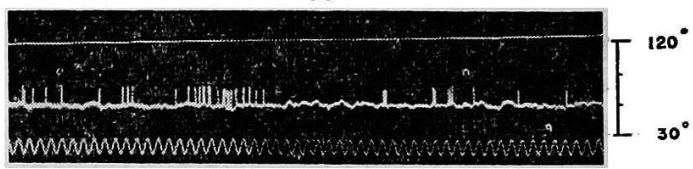

(2)

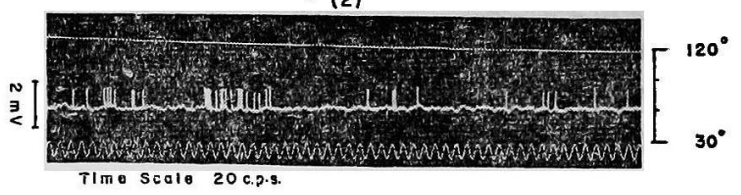


(N) 線条光の点減に対する反応
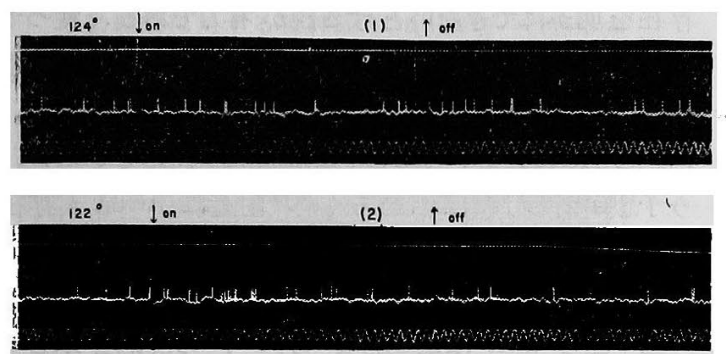

$119^{\circ} \quad \downarrow$ on

(3) $\uparrow$ off
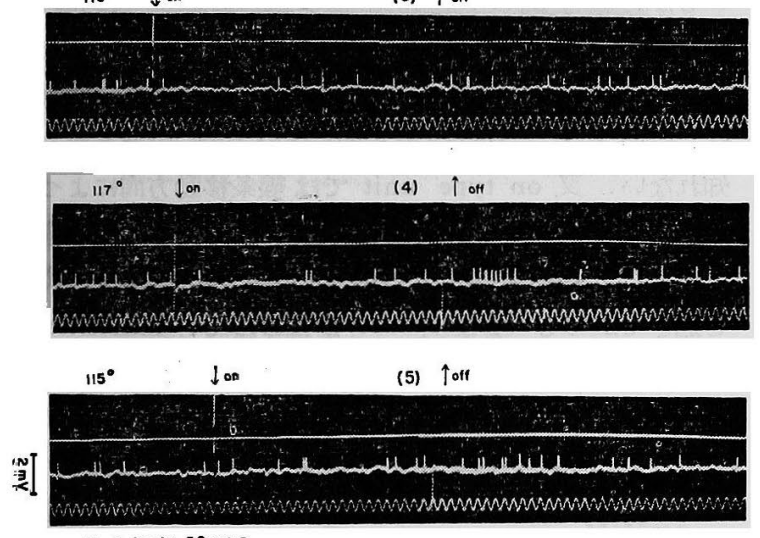

Time scale 20 c.p.s.

第8図の unit では, 線条の移動方向に無関係に, 先 ず抑制次いで反応という配列をしているのに反し，第9 図に示した unit では逆に先ず反応 次いで抑制という 配列になつている。即ら第 8 図に示した例は, 反応 unit が主として off effect response, 抑制 unit が主として on effect response であつたのに反し, 第9図の例では 反応 unit が主として on effect response, 抑制 unit が主として off effect response を示したものであろう 第9図 (II) の線条の移動速度が拈そい場合でみると， 沢・丸山等の報告している on type response K on-off inhibition の加わつた型の response を示している.

（『）の速い移動速度では， response が1籄所しか現わ れていないが，これは移動速度が速いために，点隇を急 速に行つた場合々同様に on, off の inhibition が共に on response の終つた部分にでてきたためと思われる. 移動速度の速い場合でも括そい場合でも，線条が前方上 り後方へ移動した場合（第 1 鞞が上昇する場合）の方が 抑制が早く現われている.（I）の中等度の移動速度で, 線条の後方向き移動では spike 臂が2群に分れて, 特 そい移動の場合と同じ型式の response を示し，線条の
前方向き移動では速い移動の場合と同じ pattern にな つている、そのため一見後者の方が早期に抑制が現われ るように見觉るがこの場合も実は前者の方がより早く抑 制がかつると考えるべきである，従つてこの unit では 抑制は全周から平等に受けているのでなく，網膜上では 耳側奇りに dominant の抑制野が存在していることが わかる.

(V) では $124^{\circ} て ゙$ on-off response と off の inhibition が同時に現われて拉り, off response では spike 群が 2 群に分れて， off の inhibition がある事を示して いる. $122^{\circ}$ では on の response を示し, 1190 で on の inhibition, $117^{\circ}$ では on の inhibition と off response が現われている. response type が位置によつて異なり 非常に複雑であるが, 最も強い, response は $122^{\circ}$ で, 最も強い inhibitionは1190 に現われており, 線条を迴 転した場合と同様に抑制野が網膜上や」耳側に奇つてい る事を示している，線条を固定して点隇した実験で， response pattern が非常に複雄であつた事については, Kuffler の実騟で on, off, on-off 等の response type は unit 独特のものではなく, 照射部位により反応 pattern が変る事が明らかにされているので, あえて異 とするに足らぬであろう.

第6図の unit の如く対象の移動を情報化乙得るもの を type I, 第 8 図の如く対象の移動を倩報化乙得ない ものを type II と名付ける事とする.

さて, 第 9 図の unit は強力な抑制を特定の側から受

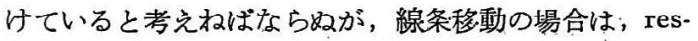
ponse と inhibition が主として時問的前後に配列し， 部位的な差は僅かしか現われない，従つて線条の移動を 橴報化する事ができず, type II に属すると思われる。 しかし第 9 図の例は抑制野が片寄つているので，抑制野 と反応野の配列は上下に重りの多い斜めの配列と考穴ら れ, 網膜上の位置と配列は第 10 図の如くであろう．抑 制野と反応野が上下配列をしている unit では, 上下に 線条を移動した場合は type I として反応する筈で, 本 啠的には type Iであり，本実験条件下に批る見脚上 の type 【一であるに䢔ぎない、眼はあらゆる方向に移 動を感知しなければならないので，上下配列も斜配列む 共に存在するのであらう。しかし，本質的な type $\mathbb{I}$ 即 ち全周から全く平等に抑制を受ける unit るないとは断 㝘できない，

抑制野と反応野の配列は，unit によつて種々である 事恃要ざ間違いないと思われるが，種々の方的性をもつ 
第 10 図 絧膜の模式圆

第9図の unit の絵膜上の位圈及ぴ反応野、 执制里の配列老示す

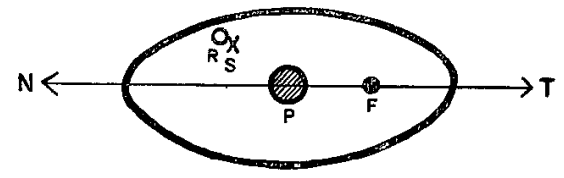

P : papilla

$F$ : fovea

$\mathrm{R}$ : receptive field

S: suppressive field

$\mathrm{N}$ : nasal side

$T$ : temporal side

た unit がでたらめに網膜上た配置されているとする と，個ヶの unit としては対像の移動を伝え得てす, 網 膜全体の情報は統一を欠き，対象物の移動を伝えるに非 常に不利となる．少くとも fovea 附近に関しては， fovea に近ずくに徉つて感度のよい receptor が配列し ていると考えられるので，偍位の inhibition はより感 度のよい fovea 側の unit から受けるとすると，最も 無理がない，即ち第 11 図に示した如く，fovea に抑制 野が向いている放線状の配列をしているものと想像され る. 従つて配列の方向によつて決まる見掛上の type I と type 【は，第12図の如き位置と配列になり，第 10 図の如き斜配列のものあ type 【に属する反応形を示 すと思われる。

\section{第 11 図網膜の模式図}

反応野之抑制野の配列方向（放䠌状配列）を示す

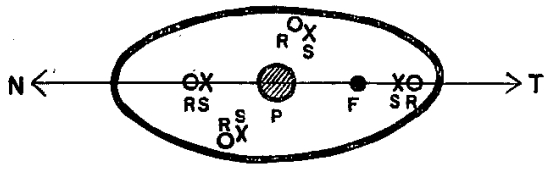

第 12 図絧膜の模式図

見卦上の type 」, type II の位置及び反応野， 排制唒の配列を示李

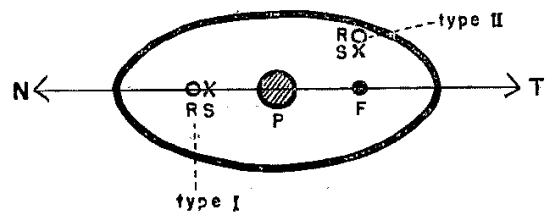

鬼の網膜の神経線維は，模云、図の犃く前後に長い棈円

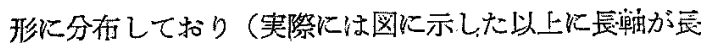
い，感受領もこれとほざ一致するものと思われる。 papilla は疼ざこの中心に在つて，䀧中央位では650 $85^{\circ}$ の方向を向を，又 $10^{\circ} \sim 15^{\circ}$ 位下方を间いている fovea の位置は人により記戴が異り, 形態学的にはその. 存在を明かにできないと方る説が有力である。従つて fovea の位置は生理学的に研究しなければならない、本: 実験だけのデータではこれを決定する事はできないが， 前記の fovea を中心にして放線状に配列儿ているとい ら予想が正しければ，恐らく300附近に，fovea が存在 するすのと想像される。従つて第6図の unit で抑制を 示した領野は fovea そのすのであろう。

第5図の unit は定型的な type I の反庀㳊示して いるが, on type の response のみを示す 4 nit で汤る. 本項の冒頭に述へた如く，視性腿振に関係する un't が on-off type を示す unitであるといら想定からすれ ば，この unit は視性腿榐と無関係の unit であるるか 知れない. 文 on type unit では線条移動方向によつ。 て、反応 patiern は㟟つてる, discharge 量は同じ筈 である・しかるに on-off type の unit であれば反応野 を過ぎからも off response が残るので, inhibition がおくれてか、ればこの off response が抑制されて discharge 量に差がでる䇢である. 即ち fovea 附近の unit でい光ば, foveo-petal より foveo-fugal $の$ 方が: より多くの discharge を出す事になり，このような機” 構があれば, fovea から対象が外れた時, 対象物を再び fovea に戾寸働きをするのに非常に好都合となる。これ， に庈し; discharge 量には変りなく, pattern のみ異る 第6 図の如き unit ではかなり複雑な中枢遗程を経てか. らでなければ筋の tonus を支配できないであろう。

fovea 近傍の unit が抑制野を fovea に局けた放線: 配列をなしているとの想定は，一度 fovea に捕えた対 象を fovea で追跡するに 好都合であるが，視野の周辺部， 迄もこのような配列であるとすると，新な対侐物が視野 の周辺部に登場した場合，これに反応して視朝をその方 に向ける眼球運動即ち急速相さ作るには不都合である。 何故ならば，新な対象は常に foveo-petal に入つて来っ. ために, foveo-petal の反応が非常に弱く筋の tonus を 変えないとすれば，急速相は棈成されれることななる。

第 13 図では反応は約 $110^{\circ}$ 附近で現われているが，北 制は網膜上でより囷䚋に存在し逆配置となつている。し かもこの unit で住 on-off unit $の$ type 1 の反応型 として考点て上い，この反応型纯第 14 図に示す吝く， 反応野の response と抑制野の response の差として考 えれば，容占に天応 patternを作図与る事ができる。

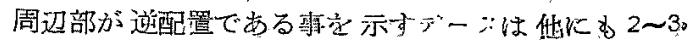


第 13 図

移動線条に対する視神経の unitary response 反応野，抑制野が逆配置を示す

(1)

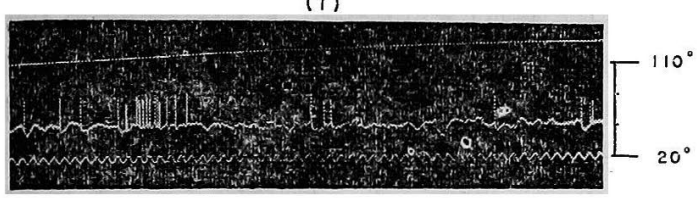

(2)

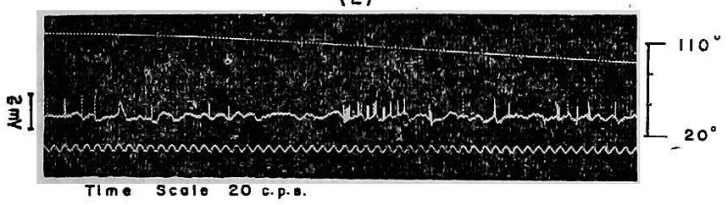

第14 図 第13図の反応 pattern の説明図 (discharge rate diagram)

（1）抑制があとからかつつた場合

(2) 抑制が先にかつつた場合

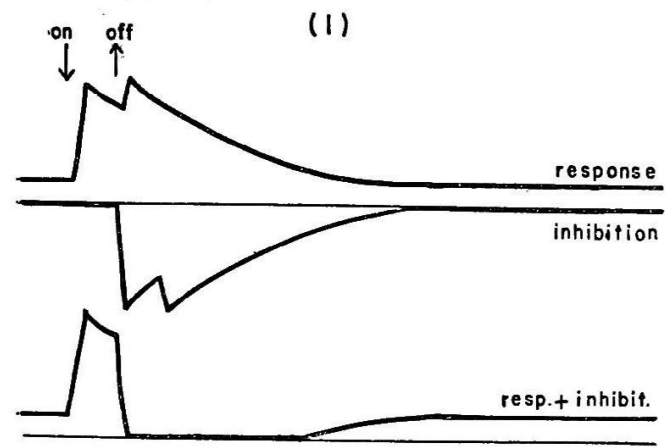

(2)

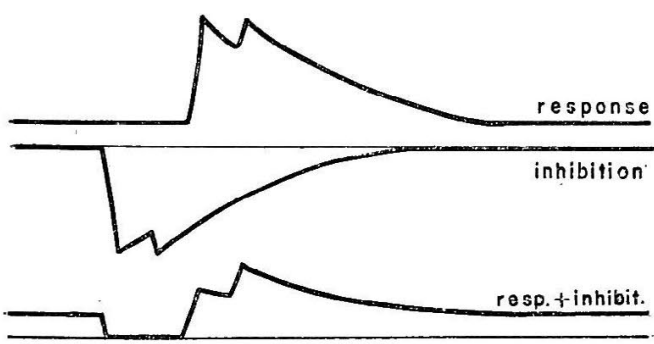

あるが，残念なことには fovea 近傍の配置を立証する データは第6図の unit のみで, しかもこの unit は視 性腿振発現に 関係がない可能性がある. 従うて fovea 近傍の unit については更にデータが必要で, 今後の実 験を企図している. fovea 近傍で type I を示す unit は fovea を通る水平線上の unit と考えられるので,
非常に捕えられる可能性が少ない，しか子も on-off response を示すbのに限られるわけである. 現在迄本項の 実験だけで 600 吹に及ぶ記録があるが， on responseを 示した第6 図の unit 以外には, fovea 近傍の unit は 1 個も捕えられていない，しかし次項の実験では，この 条件を具備確実と思われる unit が捕えられており, 且 つ重要な働きをしていると考えられたので, 本項では仮 説に仮説を重ねる事になつたが, fovea 近傍の配置を力 説したわけである.

c) 視性眼振発現時の視神経放電様式:

最後に視性眼振発現時に視神経は実際にどのような discharge pattern を示すむのであろうか. か〉る観点 から実験を進めた. 眼振発現中も, 誘導 unit の receptive field に光が照射されつば discharge が起り, 抑 制野に照射されると discharge の抑制が起り，光がこ れ等の反応野より遠ざかれば spontaneous rate に戾る という原則は, 全く同様に適用できる䇢である. 従つて E.N.G.で記録された眼球運動と, 線条の移動, discharge pattern 等から誘導 unit の網膜上の位置をある 程度推定する事ができるであろう，

視野の周辺に新な対象物が登場する事によつて, 急速 相が起るものとすれば, 恰度周辺部の unit から誘導し ている場合は, 先ず光の炤射による強い discharge が 起り，その後に急速相の発現する所見が見られる筈であ る. 㕛緩徐相が fovea で対象を追随しているために起 るものとすれば, fovea 近くの unitより誘導した場合 は, 光が照射されて discharge が增加した後では対象 が再び fovea で捕えられる方向に, 眼球が加速する所 見が見られるであろら. 即らいずれの場合でも, optic nerve の discharge が眼球運動の次の 相を規制してい る所見が見られると予想される.

第 15 図は線条の右眼向き回転によつて 相前後して起 つた視性腿振で，(2) は（1）の僅か数秒後に起つたもの である，従つて線条速度はどららも殆んど変りないるの と考えられる. spike discharge は勿論同一 unit から 誘導されたものである. 第 15 図 (2) の眼振の緩徐相 では, 初め急速に後半から緩徐になつている。これに反 し(1)では緩徐相が非常にスムースで, 眼球と線条が殆 んど一致して動いた場合と考えられる. 両者の間で線条 移動の速度は余り変りがないと思われるので，(2) の場 合も視軸が忠実に線条を追跡すれば，(1) の緩徐相と 類似の経過をとる筈である。(2) の場合, 実際には眼球 運動と線条の移動が完全に一致しなかつたものと見なさ 
第 15 図

視性眼振発現時の視神経の unitary response (右眼向き迴枟)

\section{(1)}

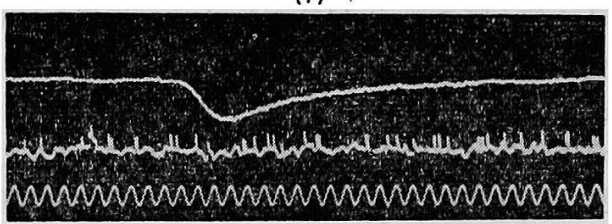

(2)

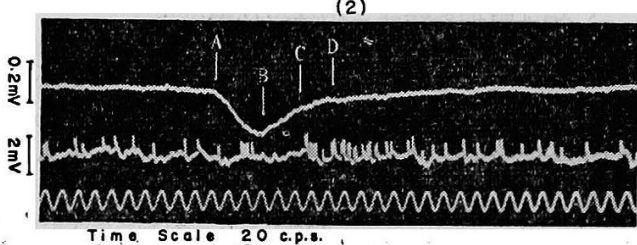

第 16 図 第 15 図の模式図

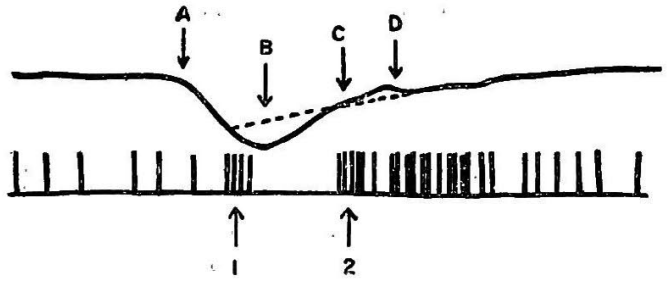

第 17 図第 15 図の場合の眼球と 線条の関係模式図（左眼）
A

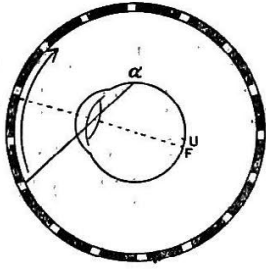

C

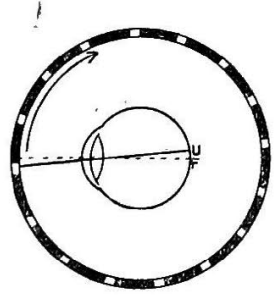

$\mathrm{U}$ : unit
B

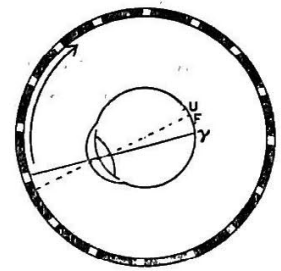

D

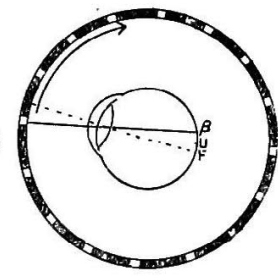

F : fovea
れるが，誘道 unit が照射を受ける位置で眼冰が忠実に 線条を追跡したもの上仮定して，その睹の E.N.G.曲線 を仮想して点線で害き入れたるのが，第16 図で㐫る。
第1の discharge む第 2 の discharge も，焉士゙線が 実際の E.N.G. 曲線をよぎる点で discharge が始ま

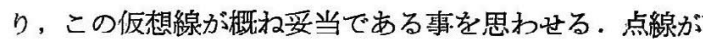
僅かながら禁曲しているのは, E.N.G. 増幅器の time constant が 0.5sec であるためであろう. E.N.G. 曲線 が点線の下にでている部分では光線が誘導 unit の耳側 登照射している事を示し，耳側照射中は強い抑制を受け ている事から， 誘導 unit の抑制野はこの unit の耳側 にあり，前項で述べた抑制野が fovea 側にあるという 原則によれば，網膜上 fovea 悬側の unit 子推定され る. 従つて (2) の眼振の経遗中 A,B, C,D で示した 時の状態を図で示せば第 17 図の如くであろう（2）の C の時点で誘導 unit が照射され discharge を起すと， その後は眼球の前方偏倚速度が著しく弱められている事 が示されている。

fovea 鼻側の照射時には眼球の前方偏倚が弱められ， 即ち後方に加速される事がわかり，これは fovea を対 象に向ける方向の運動である事が第 17 図 C'より容易に 理解される. 第 17 図 B に示した如くB時点では fovea 耳側が照射されている等である．若しこの部の unit $r$ から誘導したとすれば， B 時点で discharge が起つて いる筈である.この unit の discharge が fovea 鼻側! の誘導 unit とは逆に前方偏倚を強めれば, 即ち前方に 加速すれば，合目的々な運動を起す事になり，恐らくそ のような作用があつたために (2) の緩徐相の前半が急速 华されたものであちう. fovea の耳側の unit からの実: 際の記録については後述する. D 時点では誘導 unit の discharge はや減少しているが, "spontaneous discharge よりは discharge の interval は短くあまり強い 抑制は受けていない. しかもこの時点ではやはり fovea 鼻側の $\boldsymbol{\beta}$ unit が照射を受け，強い discharge を出し ている筈であるから, fovea 鼻側の unit 全体としては より一層強い discharge を出している筈でありっより 強い後方加速が加えられる事になる. E.N.G. 上では前: 方偏倚が弱められたのみならず，僅かながら後方偏倚が 起つた事がかかる（1）では眼振の経過すスムースで discharge 孔特に增加した時点は見当らず，対象は fovea 又は極くその近傍で捕兄られだっで推移し，誘導unit が照射される事むなからたであるう。このようにスム 一スな緩徐相が形成されるたねるは，fovea に極く近 いや今耳側の部分が照射され，適当な前方加速を保门 たま 緩徐相が経過したと考岳るべきであろう. fovea の耳側寄りが照射されて怙れば, fovea 鼻側の unit に 
抑制が起らなくとも不思議はない，しかし誘導 unit が fovea 鼻側にある以上, 第 17 図 A, B 上りわかるよう に急速相の一時期には必す照射を受けている筈であり， （1）でこれに相当する discharge の見られない事は不 可解である. しかし急速相で洆導 unit が照射を受ける のは, 網膜上 fovea に向つて像が急速に移動している 易合であるから，照射の直後に抑制がかつり，時間的に spike 咞として discharge するいとまがないという可 能性が考劣られる。これに反し (2)の C 点から D 点 にかけては，やはり対象がよぎつているけれども，抑制 が僅かである. foveo-fugal のためであろう．前項で foveo-petal と foveo-fugal で discharge 総数が異る 事を予想したが，正にその現象が現われたるのと思われ る.（2）の急速相では明瞭に discharge（第 1 の discharge）がでている.これは上記の理論に矛盾している けれども，何等かの原因で抑制がうまく働かなかつたも

第 18 図視性眼振発現時の視神絟の unuitary response（右眼向き趈転）

(1)

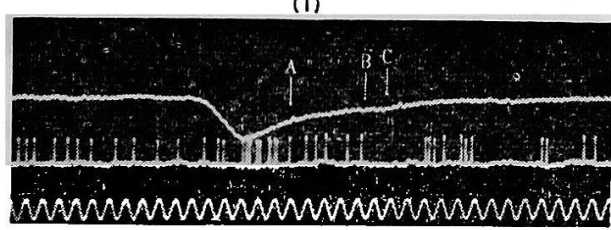

(2)
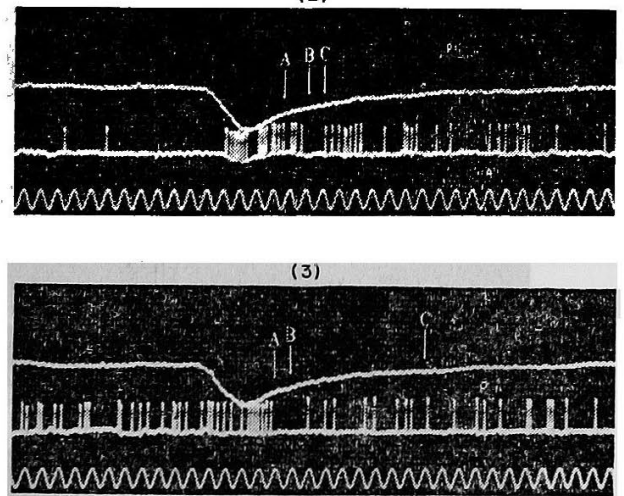

(4)

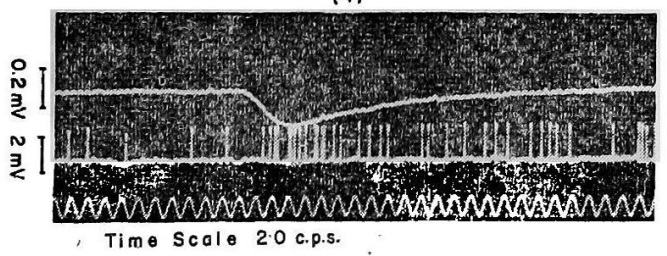

ので, そのために B 時点の邀度の後方偏倚がもたらさ

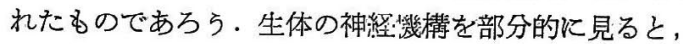
このような誤動伷，特に抑制回路の block はかなり起 りやすいものである.しかし生体は非常に多重的に支配! されているために，全体としてはあまり大きな誤動作は 起らないものである. (2) の場合は B 時点で fovea耳 側の unit が照射されて前方偏倚を蒛しく加速している と想像されたのであるが，この現象は正に 1 つの目的に 多くの回路が動員されて 1 つ誤動作をよく保償してい. る例であろち.

第 19 図視性眼振発現時の視神経の unitary response (右限向空迴枟)

(1)
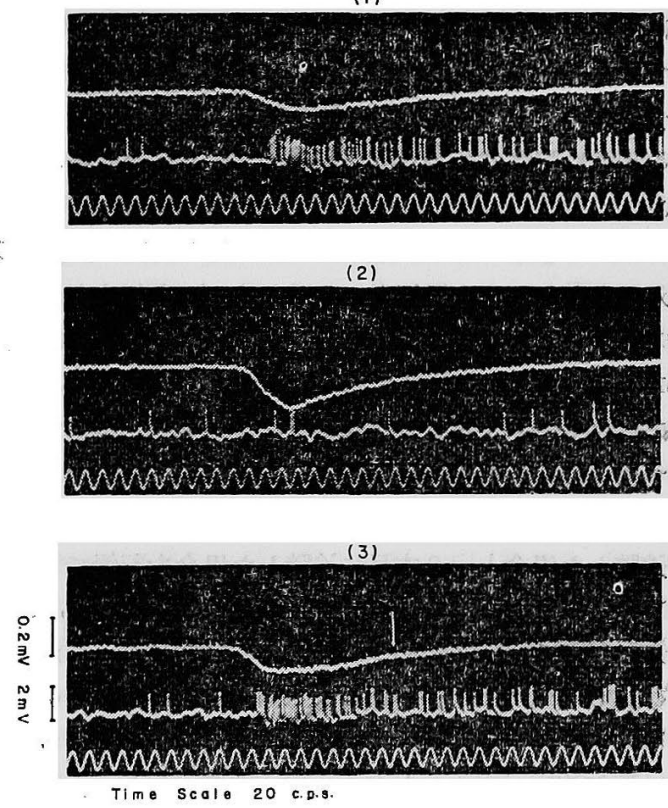

第 18 図は全体を通じて眼球が後方に (E.N.G. 上では 下方に）過度に偏倚した部分で discharge が見られる： ので, fovea 耳側の unit からの誘導と考えられるので ある. 強い discharge が起ると, 前方即ち E.N.G. で上方に偏倚が加速されている.（1）の A，B，(2）のA， (3) の A 点で discharge の減少と共に眼球の前方偏 倚の加速が終つている.（1）の C, (2) の B，(3) の B, C 点では抑制中に加速が見られているが，これは誘導 unit が, fovea からや〉離れており, 誘導 unit に対し ては抑制野をなしている部分が未だ fovea 耳側の部分 で,この部分照射により誘遒 unit は抑制を受けているけ. 
沉どす fovea 耳側の unit 全体としてはすでに discharge の增加が始り，前方への加速が行われたものであろう． (2)のC点では再度 discharge が增加して前方への再度 の加速が見られている.(2)のA点の後では加速が終つて からもなおや高頻度の discharge が 3 発出ているが， この unit に対する抑制が一時的に不完全になつたか 又は扰くれたかのいずれかであろら（4)では眼振も discharge も比較的スムースな経過をとつており, fovea 耳側のunitが照射されたま】順調に加速された場合のよ らに見えるが；付細に見ると上記同様の経過加非常に頻 “回にこまかく繰り返された場合のようである.この unit が fovea 耳側のものとすると，(4)，(2) に見られる急 、速相の discharge が一見不可解思われる. 又(1)，(3) にも不明瞭であるが同様の discharge が無いとは断言 できない風にも見觉る．これは本実験条件では殆どの場 合急速相で 1 本目の線条を跳び越して, 緩徐相は 2 本目 の線条に追随して行く事がわかつて漸く説明できたので ある. 動物の E.N.G. では振幅を眼球運動角て calibration できないために記録上では上記の説明の証拠を明 示できないが，肉眼観察では恐らく400を超すと思われ る振幅の眼振が起つている事がわかつた，線条数は全周 16 本で $22.5^{\circ}$ に 1 本宛であり, 廻転中は急速相に必要な 時間中に迴転する分だけ見掛け上更に角度が少くなる筈 であるから, 明らか跳び越しが起つていたものと考光 て間違いない，この事は第19四に示す如く，1本目に 追随した場合と，2本目に追随した場合を記録できたの で,一層確かとなつた。第19図の3つの記録は，互に 数秒間隔で連続して起つた眼振の記録であり，しかも跳 び越しのあつたと思ふれる大振幅の眼振が小振幅のもの にはさまれて記録されているので，大振幅のものだけ特 、廻転速度が変つたと考兄る事は非常に無理である.他 の記録では殆どこの大振幅のものと同程度の振幅で，小 振幅のものは他に 1 回見られたのみである. 従つて殆ど 跳び越しが起つていたと見るべきであろう.

しからば何故 1 本目に追随しないで 2 本目に追随する か，言い換、兄杖1本目の線条によつても立派に fovea 耳側の discharge が誘発されているのに, それが何故 :眼球の前方偏倚を開始せしめ得ないのか，乙かも2 本目 も同程度の discharge であろのにこれは前方偏倚を起 しているのである. この説明としては impulse の summation でもある程度説明可能であるけれども, 户はり 眼筋の緊張によつて eye-centering 的な影響があるも .のと考光た方が無理がない，第19 図は矢印の点で dis- chargeの減少により前方偏倚が弱まつているので，やは り fovea 耳側の unit と思われるが，(2) の跳び越し が起つた大振幅のるのでは，スムースな緩徐相を示し， discharge はや〉掤制されている. 従つて fovea から や〉離れた unit であろう.ところが小振幅眼振の場合 は誘導 unit が明らかに照射されている状態である. 従 つて大振幅の場合よりも網膜上ではより耳側奇りが炤射 された状態のま入経過している事になり，小振幅眼振で は第 17 図 B の如〈腿が線条のや〉後方を向いている事 になる、第19図（1）と（3）が全く同じ pattern であ る事から偶々起つた事でなく, やはり眼筋の tension receptor からの impulse が eye-centering 的影響を 与辛ているためと考えるべきである、粉ての記録で緩徐 相の終り近くのかなり眼琲が前方偏倚してしまつた部分 では, 眼琲が追随し切れなくなつて, 線条の後方に視軸 が移りつ」あると考皇ないと解釈できない pattern が必 ず見られる.これも tension receptor からの impulse によるものであろら .

第 20 图視性眼振発現時の視神経の unitary response（第 18 図と同し unit, 左眼向き迴蚣)
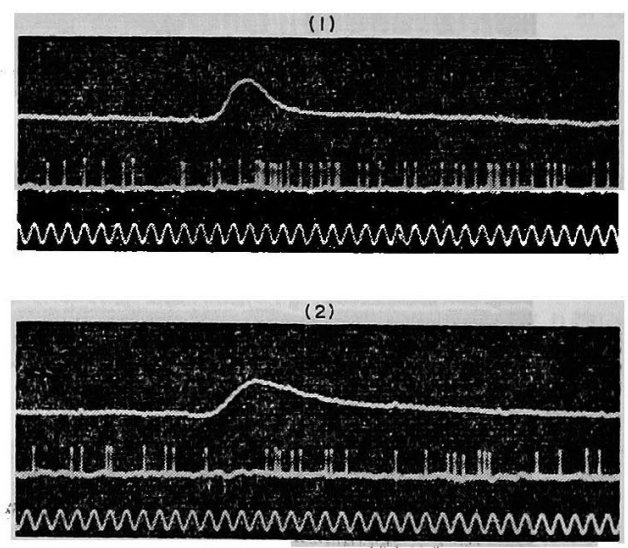

(3)

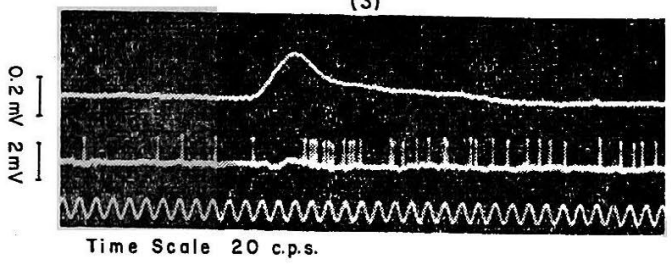

第20 図は第18 図之同じ unit で線条を左眼向きに廻 転した場合で. E.N.G. と spike discharge patternに 
第 21 図視性腿振発現時の視神経の unitary response (左眼向き趈枟)

(1)

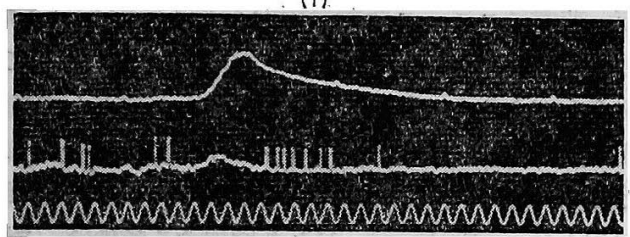

(2)

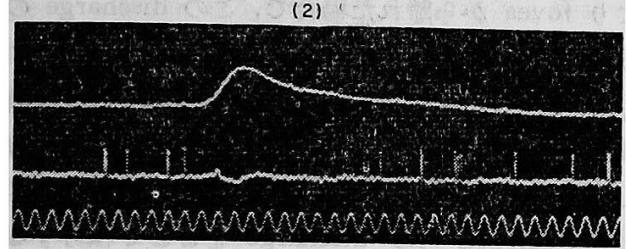

'(3)

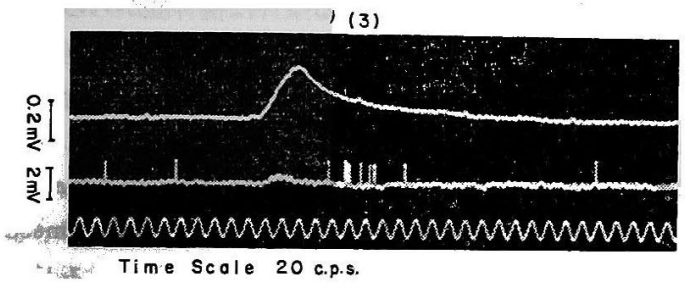

ある関係が存在する姫、見衣，右眼向き迴整之同様の説 明が可能のように見觉る．しかしこまかい点ではどのよ らに我解积つつかない矛盾を示している，第21 図では これが二霉明らかとなり，(1)と（3）はや〉侧たような pattern の如く見えるが，（2）では全く説明がつかな

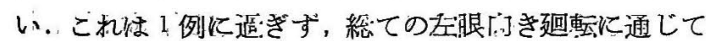
言えることである. 恐らく庄泿间き迴転時の眼振解発は 右眼が主役をなして和り，左眼の反応は対側にも線条が あつて大体に線条が等間隔のために，ほづ同じ条件で線 条が網膜に映し出される場合が多く，そのような時に特 定の pattern が見られるといらだけの事であるう.

これに反し右眼向き廷謓時の腿振で右腿が腿振解発に 関係したと解橎しなければ説明できないような場合，即 ち前記一連の解釈と全く矛盾したものは全記録 60 余り

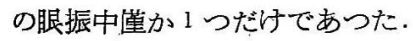

\section{考按}

以上の観察で 緩徐祦の成立には，fovea 近傍の unit が重要な役割を演じて扎り，対象が fovea から外れる と，外れたことによつて照射を受けた側の unit が discharge を起し，それに伴つて対象を再び fovea で捕促 できる方向に眼浗運動が加速される所見が見られた。上 記のような腿可運動の調整には，1 側の腿鼠:だけについ
て述べれば, fovea 學側の unit の discharge は外側? 筋の収縮を; fovea 耳側の unit の discharge は内側: 筋の収縮を促進するような反射回路が必要であらう：

又 fovea 近傍の unit は対象が fovea から外れてき た場合, 即ら foveo-fugal の刺㦸では強い discharge を起している.しかるに fovea 鼻側の unit は急速相で 必す照射を受けている筈であるのに, 著明な discharge を起さぬのが通例であつた．即ち foveo-petal の照射で はあまり強い discharge を起さ㰠らしい。この事湲 徐相の形成に一痹好都合である. 若し fovec-petal でも 同じように強い discharge を起すとすれば，急速根で は対象が fovea に近ずく程，急速相方向の眼貌速度が 益々高をる事になり，対象が fovea を不必要に行き過 ぎる事になるであろら，事実 fovea 鼻側の unit が急 速相で反応している所見が稀に見られるが，この場合眼 球の行き逅ぎが起つている場合があり，恐らく抑制 impulse がおくれたために起つた一種の誤動作と考えられ る. 勿論同時に钼察しているのは, 1つの unit に迢ぎ ないから, 観察中の unit にこのよらな誝動作が起つて も fovea 鼻側の unit 全体に起つているとは限らぬの で，眼球の行き逼ぎが必ず見られるといらおけでなかる 5 .

急速相で fovea 鼻側の unit が著明な discharge を 示さない理由として，対象が非常に速く逗ぎるという事も考えられる．しかし上記の実験条件下では多くの場 合，急速相で線条の 跳び越しが起つているので，fovea 耳側の unit も急速柏で一度は照射を受けるが，この時 の照射は foveo-fugal になるので㱠えど必す強い dischargeを出している. 従つて対象のよぎる速度だけでは 説明できない，fovea に近い unit では緩徐相に移る直 前に 2 本目の線条による discharge を今一度出してい る.これが急速相から緩徐椙へ移行する直接の原因とな るものであろら

このよらに foveo-pețal と foveo-fugal で反応が異 る理由として, fovea 近傍の unit では fovea 側に抑、 制野を有し, on-off type response を示寸事が必要であ ると予想し，上記Ｂ）項の実験では眼玟浡固定して線条 を動かし，諲導 unit の網膜上の位置を決定した上で， fovea 側に抑制野を有し映像の移動が foveo-petal か. foveo-fugal かによつて discharge 量の異る unit が存 在する事を証明しようとしたのであるが，fovea 近浐の

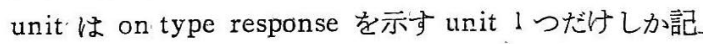
録できず，その証明には失敗した。抑制野が fovea 囎 
很ある事だけであ証明したからたのであるが，fovea の 網膜上の位置が不明であるためにすべて推論のみに終始 してしまつた: 唯抑制野が 1 側に片寄つているるのが存 在する事だけは，確実に証明できたと信ずる．

急速相が視野の周辺に新な対象物が登場する事によ つて起るすのとすると視野の周边の unit についてる fovea 鼻側の discharge は外側筇を, fovea 耳側のそ れは内側筋を収縮せしぬればよいのであるが，有効刺㦸 㤝 fovea 近傍と屰に foveo-petal でなければならな

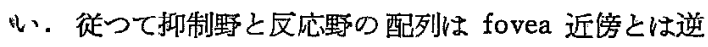
でなければならない，B）項の実験でこのような条件を 完全に具備している unit を証明できた. fovea を通る 水平線上にない, unit は，この実䟻のやり方では排制野 と反応野の配置を知る事ができない筈で，事実そのよう な上下配置と思われる unit が多く認められたので，B) 項の実験は更に実験条件を変古て検討する必要がある:

眼振を発現せしめて観察したC) 項の実験では, 急速 相を作つていると思われる unit は遂に証明できなかつ

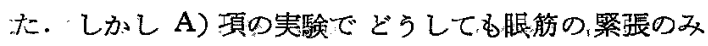
では急速相を作る原因たり得ない事を推定できたし，

吹 項で楖な対象を捕えるに好都合な抑制野の配列を認 め得たので，急速租は視野の周迅に新な対象を捕えた事 が直接の原因と考えてよからら.しかしＣ）項の実験

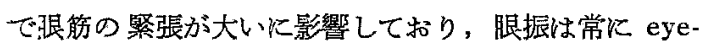
centering の基調に立つている事は間違いないと思われ z.

C) 項の実験でかかる通り，視神経の unitary discharge山概ね眼運動の加速度を指令している事になる。 しかし視性眼振に関宁する unit は on-off type と考兄 られ，しかも fovea 近倍で生 fovea 側に抑制野を有す ると考えられるので, foveo-fugal では照射がそれた挠 吸 discharge が続く筈である. 従つて対象が fovea か ら遠さかるにつれて 網膜全体では discharge が累加さ

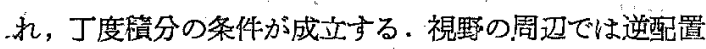
であるから，急速相を作る unit の discharge は急速 相が始まつてこの unit を外れても discharge が絸く 管であり，事実 B) 項でそのような unit が見られてい る、しかしぞららの場合も網膜全体では加速度を1 回嘪 分した状態即る速度を指令する放電量を毕すだけで，本 だ）項に見られたよらな motor pattern を合成する 事はできない，即ち免速相に例をとれば，急速相の発現 中急速相の発現を指令した discharge が少しも減少せ ずに綄いたとしてる，收縮すべき筋に行く運動神経の discharge は累加的に增加しなければならぬので，今一 度どこかで積分されねばならね：又緩徐相に例をとれ ば, 非常にスムースな緩徐相で fovea に掼く近いfovea の耳側の unit のみかー様な discharge を続けていた 場合を考えると, fovea 耳側の unit 全体としても discharge の総量は緩徐相中一様である筈である：しかる に運動神経の discharge は逐次変らねばならぬ. fovea 耳側全体の discharge がより堌加する条件は，対象が より fovea から離れた場合で,この discharge の増加 分が眼㬨の加速度として指令されねばならねわけで， unitary discharge ではこれが钼察されるわけである。 従つて緩徐相についても; 網膜全体で眼理の速度を指令 てているに過ぎない.

さて視神経からの discharge をどこで䅡分するかの 問題である.樍分を可能にする条件は視神経からの影響 がかなり長く（少くも䒘 2秒）抟つて次々に到澾する impulse $の$ 影響加 summate される 事即ち temporal summation が起る事が必要であるう。これを若し神経 機構で行うとすれば,このような性質を持つた synapsis が必要であうう.しか乙抑制 synapsis では数百 msec にわたつて影響を残すよらなものが見出されれているが， これとても時間的に未だ短か逓ざる. 㕛興奮 synapsis

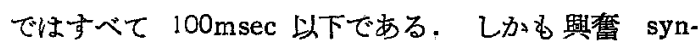
apsis でこれが行われる事が䋓対に必要である。從つて 複雑な循票回路が介在する事が想定しなげればならなく なる。

しかし眼筋運動神経核が脊䯚前角細胞と相同である事 を考光れば, 所謂 $\gamma$-system が存在するか子和れない. 現在腿筋には $r$-system が存在しないという説が有力で あるが，たとえ所謂 $r$-system は存在しなくとも機能的 にこれと相同の采が存在していないとは断言できない. 若しこのよらな糸が存在して祘れば，それによつて䅡分 作用が行われている可能性は充分考学られる。

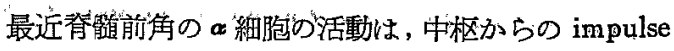
が $r$ 線維 $\rightarrow$ 筋紡錘 $\rightarrow$ 求心性線維の回路, 即占 $r$-loop 介して起される方がむしら原則のよらにざ考えられて いる、しかも皮虔反射，屈曲反射及び交性伸展反射等 で，収縮すべき筋に行く $r$ 線維の発射は $\alpha$ 細胞の活動に 符行して起る事が明らかにされている(Hagbarth(1952) 18), Eldred \& Hagbarth (1954)) 18)、即占 $\alpha$ 細胞に值 接 impulse を与学る分があるとしても，rlloop を介す る分のある事は先す間違いないらしい，従つて視性眼振 の反射回路に赫いてる同様な機序が存在するとすれば， 
A) 項で示した如き motor patternは $a$ 線維に相当す る motor pattern の活動梯式と思われるので，眼笳運 動湌に入つて来る pre-synaptic の impulse の pattern は異つているかむ知れない。

' $r$ 線維内 支配している 鏵内線維（筋紡錘内の筋線䧽） 《粘性と弾性を持つており，刺钱を続けると収縮が次第 に強をる所謂 corded contraction を行ら事が知られ ている. 即ち積分型河反応を示していると言えるである 5. しかも $\gamma$ 線維に単発刺㦸を与宁ても普通は無效で あるが，r線維に頻数刺战を゙っえて，鉦内線維を収縮さ 过た後には，同じ単発刺㦸 $(r$ 線維に対する)によって も䊉錘発射（紡錘にある感喾器か5の impulse）が著明 飞增強し，その促通効来忙 7 分にる及心場合があるとい 5 (Hunt \& Kuffer (1951)) :3). 従つて $\gamma$ 柔又心相 同の系が腿筋にも存在するとすれば，この部位で樍分が 行われる可能性は充分に考光られる。

上記の推論が正しければ，視性眼振反射の中枢嘰序は 非常に簡単でよい事になり，中枢核に扰ける synapsis では上位中枢及び迷路からの影響を統合するのが主な役 具となり, 視性 impulse そのもの〉 modulate は殆ど 行われない事になろら。

しかし $r$ 系又はこれと相同の系がないとすれば，視 性眼振の中枢機序は非常に複雑でなければならず，恐ら く循鄸回路を必要とするであろう。この問題に対する決 め手は眼筋運動核への pre-synaptic impulse を観察す る事であろう. eye-centering に必要な脇肉からの感覚 性 impulse は収縮の絶対值を伝える必要があるので， 当然腱紡鉭又はそれと相同機能を有する筋觉受容器から 送られるものと思われる.迷路性の眼振では急速相を作 るための特別の impulse を迷路から送る可能性は殆ど 考えられないので, eye-centering の作用が非常に重要 となるであるら。従つて眼筋に全く tension receptor がないとは到底考えられない。

\section{紹 括}

視性眼振反射路の神経機序を究明するために, 超微小 電極法に上り，眼筋運動刻及び視神経の unitary response を記録検討した。

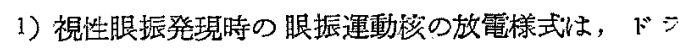
么迴転と同時に一定限度をで, discharge rate の增減が 起り，眼振が登現する迄は增加又は減少したまっで， discharge rate が維持されて扣り，眼球が偏倚した位 置で待機している事を思わせる。

2) 眼振急速相発現と同時に，光ず弘緩僓眼筋への discharge rate $は 一$ 頓に最小頻度に迄低下し, 緩徐相 発現と共に徐々潧加する：急速相発現時に收縮与る側 の discharge rate は眼振各相の経逗と一致して変化す る.

3) 眼振発現時, fovea 近傍に receptive field を有す る視神経 unit の spike discharge は, 対象が fovea をそれて热射を受けた時に discharge が增加し, 眼㩧 電図上ではその直後から対象が 再び fovea で捕えられ る力向に眼轨運動が加速される所見が常に認められた. fovea近傍の unit では網膜上 foveo-fugal に対象が 移動した場合に特に強い response を示し, foveo-petal の移動では㩘朋な response を示さない場合が多く、楥 徐相形成に好都合な性質を有する。

4) fovea 近傍の unit $か ゙$ foveo-fugal $と$ foveo-petal で別の反応態度を示す原因を究明するために，眼球を不 動化して線条を移動し，視神経の unitary response を記録険討した. fovea 近傍の unit が1個しか記録で きなかつたために，上記の原因を明らかにする事はでき なかつたが1側のみに特に dominant な抑制野を有す る例が数例認められ，移動目標化対する視神経の情報型 式を推定する事ができた。

5.) 視野周辺部の unit で注抑制野を外側に持つ unit が認められ fovea 近傍とは逆化 foveo-petal の移動が より有効な刺㦸となつている事がわからた。急速相形成 に好都合な性質を有しているものと思われる。

6) 眼振発現時の視神経の discharge pattern の分析 から，線条の右眼向き迴転では主として交眼か眼振解発 に関与している事が明らかとなつた。

7) 上記実験の結果から, 視性眼振緩徐相は fovea で 対象を追求せんとする反応であり，急速相は視野にはい つてきた新な対象に対する視軸の転腪である。といら考 え方が概ね正しいもの之思われる。しかし眼振各相を通 じて eye-centering の基調が働いている事は事実であ り，眼筋の tension receptor からの影響も否めない.

文献

1) Adrian, E.D.: Afferent discharge of the cerebral cortex from peripheral sense organs. J. Physiol., 100: 159, 1941. 2) Anderson, S. and B.E. Gernandt: Cortical projection of vertibular nerve in cat, Acta Oto-laryng., 116:10,1954. 3) Bárány, R.: Weitere Untersuchungen über den vom Vestibularapparat des Ohres reflelstorischen ausgelösten rythmischen Nystagmus und seine Begleiterscheinu- 
ngen. Mschr.:Ohrenh., 41: 477, 1907. 4) Bárány, R.: Zur Kliniks und Theorie des Eisenbahner Nystagmus, Acta Oto-laryng., 3:260, 1921. 5) Bartels, $M$ :: Ophthalmostatik und Ophthalmokinetik. Arch. Ohrenh., 118:270, 1927. 6) Bender $M, B .:$ Centering of eyes. Arch. Neurol. Psychiat., 72: 282, 1954. 7) Bender, M.B.: The eye-centering system. Arch. Neurol. Psychiat, 73: 685, 1955. Bleeker, J.D.J, and Hl. de Vries: The microphonic activity of the labyrinth of the pigeon. Acta Oto-laryng., $37: 289,1949$. 9) Brunner, H.: Über labyrinthäre und optokinetische Übererregbarkeit. Neurenarzt., $9: 244,1936$. 10) Conen, M.J.: The function of receptors in the statocyst of the Lobster humarus americans. J. Physiol., 130: 9, 1955.

11) Crammer, $K$. N Nystagmus related to lesion of the cerebelum., Ann. Oto-laryng., 60: 186, 1951.

12) Eckel, E.: Electrophysiologische und histologische Untersuchungen im Vestibulariskerngebiet bei Drehreizen. Arch. Ohrenh., 164: 487, 1954.

Eldred, E. and K.E. Hagbarth: Facilitation and inhibition of gamma efferents by stimulation of certain skin areas, J. Neurophysiol., 17 : 59, 1954. 14) Fischer, J.J.: The labyrinth, New York, Grune and Stratton, 1956.15$)$ Gernandt, B.E. and C.A. Thulin: Vestibular connection of the brain stem. Amer, J. Physiol., 171: 121,.1952. 16) Gernandt, G.E. and C.A. Thulin: Vestibular mechanismus of facilitation and inhibition of cord reflexes, Amer, J. Physiol., $171: 653,1953$. 17) Gernandt, B.E.,Y. Katsuki and R.B. Livingston: Functional organization of descending vestibular influences. J. Neurophysiol., 20: 453, 1957. 18) Hagbarth, K.E.: Excitatory and inhíbitory skin areas for flexor and extensor motoneurons, Acta Physiol. Scand,, 26: Suppl. 94, 1952. 19) Hartline, H.K.: The response of single optic nerve fibers of the vertebrate eye to illumination of the retina, Amer. J. Physiol.. $121: 400,1938$. 20) Hartline, H.K.: Receptive field of the optic nerve fibers. Amer. J. Physiol., $130: 690,1940$, 21) Hartine, H.K., H.G. Wagner and F. Ratliff: Inhibition in the eye of Limulus, J. Gen. Physiol., 39:651, 1956. 22) Huizinga, E.: Über die Funktion des Bogengangapparates bei der Taube. Arch. Ges. Physiol., 231 : 525, 1933. 23) Hunt, C.C. and S.W. Kuffer: Further study of efferent small-nerve fibers to mammalian muscle spindles, Multiple spindle innervation and activity during contraction, J. Physiol., 113: 283, 1951. 24) Jung. R.: Handuch der inneren Medizin : Neurologie. Berlin, Springer, 1953. 25) Kestenbaum. A.: Zur Klinik des optokinetischen Nystagmusy. Arch. Ophth., 124: 339, 1930. 26) Kuffer, S.W, Discharge pattern and functional organization of mammalian retina, J. Neurophysiol., 16:37, 1953. 27) Lennox, M.A. and A. Madsen: Cortical and retinal response to colored light flash in anestheti zed cat. J. Neurophysiol., 18:412, 1956. 28) Low. enstein, $O$. and $A$. Sand: The individual and int. egrated activity of the semicircular canal of the Elasmobranch labyrinth, J. Physiol., 99 : 89, 1941.** 29) Meessen, H. and J. Olszewsky: Cytoarchitektonischer Atlas des Rautenhirns des Kaninchens, Basal, S. Karger, 1949 . 30) Monakow. C.: Die Lokalization im Grosshirn, Wiesbaden; J.F. Bergman. 1914. 31) Mygind, $H$.: Mechanismus of vestibular manifestation in intracranial lesions. Acta Oto-laryng, $43: 291.1953 . \quad 32)$ Spiegel, E.A. and N.P. Scara: Positional nystagmus in cerebellar lesion. J. Neurophysiol., $5: 247,1942$. 33) 'Spiegel, E.A. and N.P. Scara: Response of labyrinthine apparates to electrial stimulation. Arch. Oto-laryng. 37: 745, 1943. 34) Wilmer, W.H.: Atlas fundus oculi, New York, Macmillan Comp., 1934, 35) 福

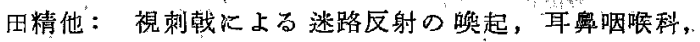
28：699，1956。 36) 福田精他：，視性眼振より見太䞤 転性眼振の生理, 日本耳粤咽喉科学会会報, 60 臨時号:

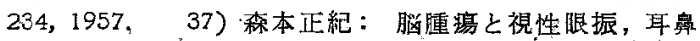

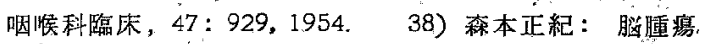
の耳科学的研究, 日本耳鼻咽咆科学会会数, 58: 1374, 1955, 39) 本川弘一：䙺党の生理学, 脳之神経, . 7 : 247, 1955. 40) 小川鼎三: 脳の解剖学, 昭 26. 41).

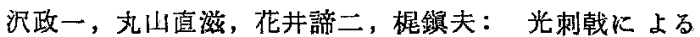
視神経の unitary activity について, 第 7 回日本膗波. 学会 (演), 昭 33. 42) 島津浩: $r$ '系の生理, 神怒研 究の進歩，3:781，1959.43）富田恒夫，村上元产: 絧膜の神経生理，神経研究の進步，2：792, 1958. 44) 島津孝道：実験動物解剖学, 金原出版株式会社, 昭29.

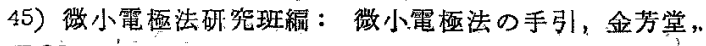
昭 32 .

船を終るに当り，御指尊，御校閲を睗り乙恩 “師森本正紀教授，丸山直湤助教授に樑甚なる謝 意を表すると共に，実験に御援助戴いた萓野裁 信，间崎匡両先生の御厚情に感謝致します

(原稿到着 $=$ 昭和 34.12 .14 日) 